University of Nebraska - Lincoln

DigitalCommons@University of Nebraska - Lincoln

10-17-2002

\title{
An Evolutionary Perspective of Pierce's Disease of Grapevine, Citrus Variegated Chlorosis, and Mulberry Leaf Scorch Diseases
}

Jianchi Chen

Florida A\&M University

John S. Hartung

USDA-ARS, Beltsville Agricultural Research Center, Beltsville, MD

Chung-Jan Chang

University of Georgia, Griffin

Anne K. Vidaver

University of Nebraska-Lincoln, avidaver1@unl.edu

Follow this and additional works at: https://digitalcommons.unl.edu/plantpathpapers

Part of the Plant Pathology Commons

Chen, Jianchi; Hartung, John S.; Chang, Chung-Jan; and Vidaver, Anne K., "An Evolutionary Perspective of Pierce's Disease of Grapevine, Citrus Variegated Chlorosis, and Mulberry Leaf Scorch Diseases" (2002). Papers in Plant Pathology. 88.

https://digitalcommons.unl.edu/plantpathpapers/88

This Article is brought to you for free and open access by the Plant Pathology Department at DigitalCommons@University of Nebraska - Lincoln. It has been accepted for inclusion in Papers in Plant Pathology by an authorized administrator of DigitalCommons@University of Nebraska - Lincoln. 


\title{
An Evolutionary Perspective of Pierce's Disease of Grapevine, Citrus Variegated Chlorosis, and Mulberry Leaf Scorch Diseases
}

\author{
Jianchi Chen, ${ }^{1}$ John S. Hartung, ${ }^{2}$ Chung-Jan Chang, ${ }^{3}$ Anne K. Vidaver ${ }^{4}$ \\ ${ }^{1}$ Division of Agricultural Science, Florida A\&M University, Tallahassee, FL, USA \\ ${ }^{2}$ Fruit Laboratory, USDA-ARS, Beltsville Agricultural Research Center, Beltsville, MD, USA \\ ${ }^{3}$ Department of Plant Pathology, University of Georgia, Griffin, GA, USA \\ ${ }^{4}$ Department of Plant Pathology, University of Nebraska, Lincoln, NE, USA
}

Received: 7 February 2002 / Accepted: 7 March 2002

\begin{abstract}
Xylella fastidiosa causes diseases on a growing list of economically important plants. An understanding of how xylellae diseases originated and evolved is important for disease prevention and management. In this study, we evaluated the phylogenetic relationships of $X$. fastidiosa strains from citrus, grapevine, and mulberry through the analyses of random amplified polymorphic DNAs (RAPDs) and conserved 16S rDNA genes. RAPD analysis emphasized the vigorous genome-wide divergence of $X$. fastidiosa and detected three clonal groups of strains that cause Pierce's disease (PD) of grapevine, citrus variegated chlorosis (CVC), and mulberry leaf scorch (MLS). Analysis of 16S rDNA sequences also identified the PD and CVC groups, but with a less stable evolutionary tree. MLS strains were included in the PD group by the $16 \mathrm{~S}$ rDNA analysis. The Asiatic origins of the major commercial grape and citrus cultivars suggest the recent evolution of both PD and CVC disease in North and South America, respectively, since $X$. fastidiosa is a New World organism. In order to prevent the development of new diseases caused by $X$. fastidiosa, it is important to understand the diversity of $X$. fastidiosa strains, how strains of $X$. fastidiosa select their hosts, and their ecological roles in the native vegetation.
\end{abstract}

Strains of Xylella fastidiosa cause various diseases on many economically important plants [15], and the list of new hosts and diseases continues to expand to include coffee [8], oleander [22], and avocado (William Villa Lobos, pers. comm). With one exception [18], all reported diseases caused by $X$. fastidiosa were from the Americas, where strains of the pathogen have long been known to be endemic in the native flora [9, 24]. Transmission of the pathogen is insect mediated, and the bacterial population is thought to be restricted to the xylem vessels in the plant hosts. Two diseases caused by $X$. fastidiosa, Pierce's disease (PD) of grapevine (Vitis vinifera L.) and citrus (Citrus sinensis) variegated chlorosis (CVC), are currently epidemic in USA and Brazil, respectively. The high economic impact of CVC disease led to substantial effort to sequence the complete genome of $X$. fastidiosa strain 9a5c, which became the first plant pathogenic bacterium to have its genome completely sequenced [28]. The sequence of a California PD strain

Correspondence to: J. Chen; email: jianchi.chen@famu.edu genome has also been completed by the same team in Brazil (Edwin Civerolo, pers. comm.).

Although PD of grapevine was first described in Southern California, it is generally believed that the pathogen originated from the southeastern USA because most Vitis species native to this region are resistant to the disease. Hewitt [13] hypothesized that the bacterium was spread to California through propagation materials. When CVC was first described [26], it was already widespread in the citrus growing region in Brazil and Argentina [2]. The origin of CVC strains and the cause of the disease epidemic are still not clear. The CVC strains isolated from Brazil are genetically homogeneous [23, 25].

The major commercial grape and citrus cultivars are derived from Vitis vinifera and Citrus spp., respectively. The geographical origins of the two crops are in Asia [7, 11]. The relationship between the occurrence of PD and CVC and the introduction of their host crops, as well as insect vectors and environmental interactions, deserves 
close examination. It is currently believed that the establishment of the glassy winged sharpshooter, Homalodisca coagulata, in California [20] is responsible for the recent severe outbreak of $\mathrm{PD}$ there.

$16 \mathrm{~S}$ rDNA sequences from 16 strains of $X$. fastidiosa, isolated from nine host plants, were obtained and compared [5]. All of these $16 \mathrm{~S}$ rDNA sequences were at least $99 \%$ similar, consistent with the results reported recently [19]. Detailed analysis of these similarity values revealed three rDNA groups composed of strains of PD, plum leaf scald, and CVC [5]. Interestingly, the mulberry leaf scorch (MLS) strains in this study were more closely related to PD strains, consistent with previous RFLP and RAPD studies using single or double strains [3, 21]. The MLS strains were from either Massachusetts or $\mathrm{Ne}$ braska, regions with winter temperatures much colder than warm areas where $X$. fastidiosa is known to cause disease problems, such as PD and CVC.

Knowledge about the origin and evolution of diseases caused by $X$. fastidiosa is important because it will provide key information towards disease prevention and management. In this study, we focused on three groups of $X$. fastidiosa strains isolated from citrus, grapevine, and mulberry. The geographical sites of isolation of the three strains span the Americas. Phylogenetic relationships among the three groups of bacterial strains were separately estimated by two methods. 16S rDNA sequences were selected to provide data from a highly conserved gene from the genome. These data were contrasted with data derived from genomic RAPD fragments, which are considered to be randomly selected from the whole genome and very variable. Two phylogenetic estimates were compared and discussed in light of the host origins.

\section{Materials and Methods}

Bacterial strains and DNA isolation. $X$. fastidiosa strains used for RAPD analysis in this study included five PD strains (OS29-5, OS30-5, CAR1-5, CAR2-5, and CAR3-5) isolated from northern Florida; nine MLS strains (MUL-1, 2, 4-10) from Nebraska; and five CVC strains (PLANT5, PW, 93-1, 93-2, and 94-2) from Brazil. Strains of $X$. fastidiosa from plum (PLS 2\#9) and oak (Stucky I) were included for comparison. Three strains of Xanthomonas campestris pv. campestris (XAN-L7, XAN-L22, and XAN-L230) and two strains of X. campestris pv. vesicatoria (XAN-G18 and XAN-G38) were used as outliers. Bacterial DNA was either isolated directly from agar cultures according to the procedure of Albibi et al. [1] or from broth as described previously $[4,21]$.

RAPD analysis. Fifteen 10-base primers (OPA-01, OPA-02, OPA-03, OPA-04, OPA-07, OPA-08, OPA-10, OPA-11, OPA-12, OPA-13, OPA-14, OPA-16, OPA-18, OPA-19, and OPA-20) were purchased from Operon Technologies, Inc. (Alameda, CA). PCR experiments were performed as previously described [1]. RAPD profiles were scored in a binary format. Phylogenetic analysis was done by using the FreeTree program [10]. The Dice distance was calculated, and a phy- logenetic tree was constructed by the neighbor-joining method [27] with the Xanthomonas strains as an outgroup. The reproducibility of the tree was assessed by performing 1000 bootstrap analyses.

16S rDNA sequence analysis. Twenty $16 \mathrm{~S}$ rDNA sequences of $X$. fastidiosa were retrieved from the GenBank DNA database. The source strains and related information are provided in Table 1. The 16S rDNA sequences were first aligned, and nucleotide positions that were variable for multiple strains were identified manually. The Clustal X program [29] was used for data analysis. A phylogenetic tree was constructed with the neighbor-joining method, with two 16S rDNA sequences from Xanthomonas campestris (AF159581 and AF123092) as an outlying group. The reproducibility of the resulting tree was assessed by performing 1000 bootstrap analyses.

\section{Results and Discussion}

RAPDs vs. 16S rDNA sequence analyses. The phylogenetic relationships among the studied bacterial strains, based on 115 scorable RAPD characters, are shown in Fig. 1. X. fastidiosa strains representing CVC, PD, and MLS form three distinct phylogenetic branches, with bootstrap values of $100 \%, 100 \%$ and $97 \%$, respectively. A branch containing plum leaf scald and oak leaf scorch strains is also present, but this is a much less robust branch with a bootstrap value of $78 \%$. A recent study [23] based on REP, ERIC, and RAPD analyses also demonstrated the presence of the same four groups within $X$. fastidiosa. As expected from a previous study [5], the phylogenetic tree based on 16S rDNA sequence identified the CVC, PD, and plum leaf scorch branches (Fig. 2). MLS strains are included in the PD branch. However, the bootstrap values for each branch are lower than for the corresponding branches in the phylogenetic tree generated from RAPD-PCR data (75\% for PD-MLS strains, $68 \%$ for CVC-coffee leaf scorch strains, and $40 \%$ for plum leaf scorch- phony peach-oak leaf scorch strains).

The differences in the stability of the branches of the two phylogenetic trees can be explained as follows: The RAPD-PCR method is a multilocus analysis that we consider to sample the whole genome, while the $16 \mathrm{~S}$ rDNA locus is highly conserved in eubacteria. The apparent rate of evolution at the level of the whole genome is, therefore, expected to be faster than that of the conserved 16S rDNA. In fact, RAPD-PCR analysis is known to detect more polymorphisms and so is suitable for closely related strains $[4,23]$. The unstable $16 \mathrm{~S}$ rDNA tree indicates that the divergence of the $X$. fastidiosa strains was recent, although the divergence time remains to be investigated.

A much more distant branch is represented by the pear leaf scorch strain (PE.PLS) and a plum leaf scorch strain (PL.788), based on the 16S rDNA data (Fig. 2). Such a distant branch, represented by PE.PLS, was ob- 
Table 1. List of bacterial strains, hosts, and origins of 16S rDNA sequences

\begin{tabular}{|c|c|c|c|c|}
\hline Name of bacterial strain & Host & Origin of isolation & $\begin{array}{c}\text { Accession } \\
\text { number }\end{array}$ & Source of sequencing \\
\hline PCE-FF (ATCC $\left.{ }^{a} 35879\right)$ & Grapevine & Florida & AF192343 & J. Chen ${ }^{b}$ \\
\hline GR.8935 (ATCC 35879) & Grapevine & Florida & AF203391 & Y. Rosato ${ }^{c}$ \\
\hline PCE-FG (ATCC 35881) & Grapevine & Florida & AF159572 & J. Chen \\
\hline R116v11 & Grapevine & Georgia & AF159573 & J. Chen \\
\hline PD 28-5 & Grapevine & Florida & AF159574 & J. Chen \\
\hline MUL1 (ATCC 35868) & Mulberry & Massachusetts & AF224740 & J. Chen \\
\hline MUL-2 & Mulberry & Nebraska & AF159576 & J. Chen \\
\hline $9 \mathrm{a} 5 \mathrm{c}(\mathrm{rrnaA} 16 \mathrm{~S}-1)$ & Citrus & Brazil & NC_002488 & Simpson et al. ${ }^{d}$ \\
\hline 9a5c (rrnaA 16S-2) & Citrus & Brazil & NC_002488 & Simpson et al. \\
\hline CI.52 & Citrus & Brazil & AF203389 & Y. Rosato \\
\hline Plant-5 & Citrus & Brazil & AF224736 & J. Chen \\
\hline CVC 93-2 & Citrus & Brazil & AF159575 & J. Chen \\
\hline Found 4 & Coffee & Brazil & AF224737 & J. Hartung ${ }^{e}$ \\
\hline Café 20 & Coffee & Brazil & AF224739 & J. Hartung \\
\hline $\mathrm{CO} .01$ & Coffee & Brazil & AF203390 & Y. Rosato \\
\hline OAK (ATCC 35874) & Oak & Washington, DC & AF224735 & J. Hartung \\
\hline PP4\#5 & Peach & Georgia & AF159580 & J. Chen \\
\hline PLS 2\#9 & Plum & Georgia & AF159579 & J. Chen \\
\hline PL.788 (ATCC 35871) & Plum & Georgia & AF203388 & Y. Rosato \\
\hline PE.PLS & Pear & Taiwan & AF203392 & Y. Rosato \\
\hline
\end{tabular}

${ }^{a}$ American Type Culture Collection, Rockville, MD, USA.

${ }^{b}$ Literature Cited, No. 5.

${ }^{c}$ Literature Cited, No. 19.

${ }^{d}$ Literature Cited, No. 28.

${ }^{e}$ Literature Cited, No. 5.

served recently [19]. However, strain PL.788 was grouped into the plum leaf scald branch represented by PLS2\#9 [19]. Direct sequence comparison shows that the number of nucleotide differences between AF203388 (PL.788) and AF203392 (PE.PLS) is only 3, whereas the number of nucleotide differences between AF203388 and AF159579 (PLS2-9) is 28. Others have shown that plum leaf scorch can be caused by widely divergent strains from both North and South America [6], so the presence of diversity within the group of plum strains at the $r r n$ locus is not completely surprising. RAPD analysis was not performed on strain PL.788 and PE.PLS in this study.

Evolution of Pierce's disease of grapevine and citrus variegated chlorosis. While the precise time of divergence of the $X$. fastidiosa PD and CVC strains is unknown, the evolution of both PD and CVC disease in North and South America can be traced. Cultivation records of both grape and citrus support the theory that both PD and CVC have developed recently. Vinifera grape was first grown in Southern California in the 1770s, but the first PD outbreak was not until the 1880s [13]. Since that time, nearly all viticulture was forced to move northward. The century of PD-free viticulture in Southern California was probably owing to the late introduction of the PD bacterium from the
Southeast. In Florida, the introduction of vinifera grapes has never been successful because of the rapid development of PD, with the destruction of grapevines within 1 to 5 years [15].

Like PD strains, CVC strains are genetically highly homogeneous [23, 25], and citrus (Citrus spp.) was introduced from Asia [7]. In Asia, CVC has not been reported, despite thousands of years of citriculture. As was the case with PD in California, CVC was described in the 1980s after a short history of extensive cultivation in Brazil, in this case less than 50 years. Interestingly, citrus has been extensively grown in Florida for over a hundred years. CVC has not been found, although a strain of $X$. fastidiosa was reported to be associated with citrus [14]. CVC disease may have been preceded in Brazil by the recently described coffee leaf scorch or requiema do café. This disease has recently been shown to be endemic in the coffee-producing regions of São Paulo State and to be very closely related to the citrus strains of CVC $[8,23]$. Because the citrus industry replaced the coffee industry in São Paulo after the coffee industry had experienced a prolonged decline, it is likely that the CVC strains were originally selected from coffee [17]. This is consistent with the phylogenetic relationships among this group of strains (Fig. 2). 


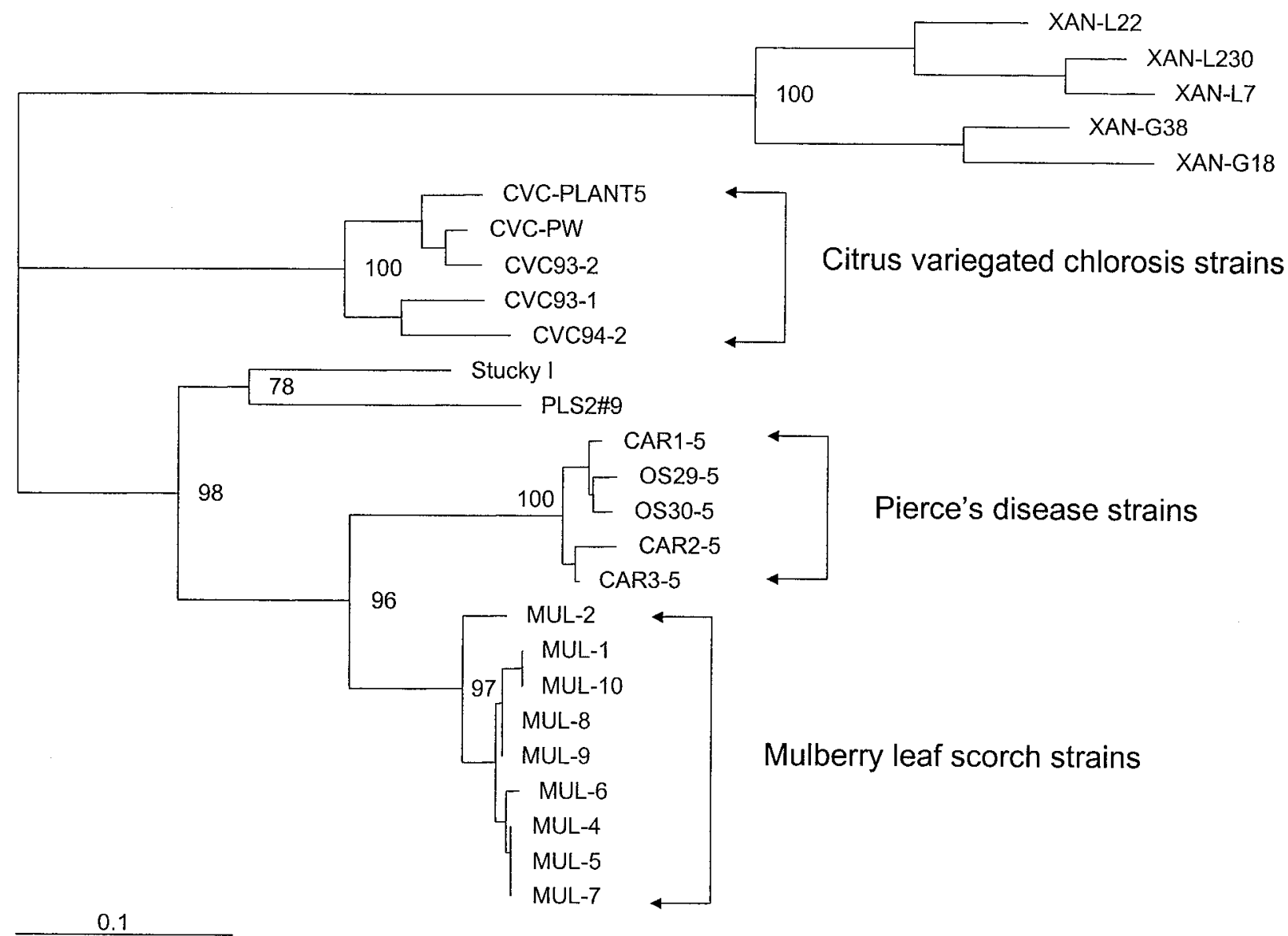

Fig. 1. A phylogenetic tree constructed by the neighbor-joining method based on 115 RAPD characters of 26 strains of Xylella fastidiosa and Xanthomonas campestris. The numbers at the selected nodes indicate the levels of bootstrap support (percentage) based on 1000 re-sampled data sets. The scale bar represents $10 \%$ of genome divergence.

Pierce's disease and mulberry leaf scorch strains. We infer that the evolutionary divergence between PD and MLS strains was more recent than that between PD and CVC strains (Figs. 1 and 2). Pierce's disease strains are limited to the warm climates in the Southern USA, but the MLS strains are from the cold regions of the North and Northeastern U.S. In view of the close phylogenetic relationship demonstrated in this study, two questions are raised: Can PD and MLS strains cross-infect their hosts? And, how are MLS strains able to survive the cold winter temperature environment when PD strains can not? Answers to these questions will directly influence the management of grape diseases in the Northern USA, where grape cultivars were bred from the PD-susceptible species, such as $V$. labrusca, $V$. riparia, and $V$. vinifera. No cross-infectivity data between PD and MLS strains are available, but grapevine has been infected experimentally by even more distantly related strains: Hendson et al. [12] reported that some almond leaf scorch strains that caused symptoms of PD were actually more closely related to plum leaf scald strains. A periwinkle strain of $X$. fastidiosa could multiply in grapevine but did not cause symptoms [15]. This strain was grouped with grapevine strains on the basis of RAPD-PCR data in another study [21]. These host range data are consistent with the idea that individual strains of $X$. fastidiosa can infect and multiply to a greater or lesser degree in many plant hosts.

With limited information, it is difficult to discuss the development of MLS. Both red mulberry (Moris rubra, native to Northeastern USA), and white mulberry ( $M$. alba, native to China) are common in the USA. In Nebraska, MLS was found in both red mulberry and white mulberry. The disease was first seen at least 5 years ago, and the incidence has increased in the last few years. MLS has been reported to be common in the red mulberry tree (M. rubra) in the Northeastern USA [16]. Interestingly, there has not been any report about MLS from Asia, where the white mulberry has been cultivated for thousands of years. 


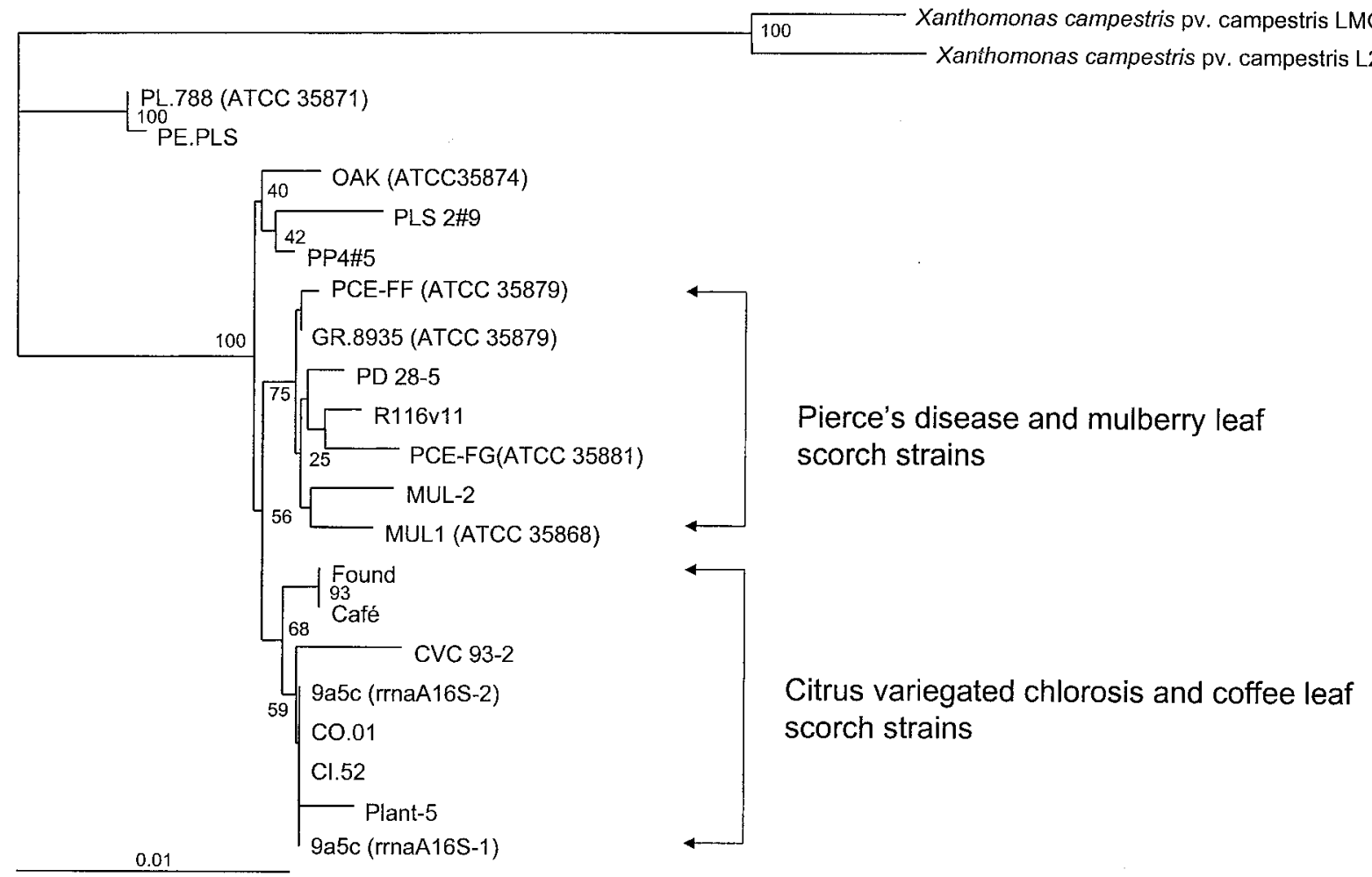

Fig. 2. A phylogenetic tree produced with the neighbor-joining method based on near-complete 16S rDNA sequences of 20 strains of Xylella fastidiosa and two strains of Xanthomonas campestris. The numbers at the selected nodes indicate the levels of bootstrap support (percentage) based on 1000 re-sampled data sets. The scale bar represents $1 \%$ of sequence divergence.

Ecological perspectives of $X$. fastidiosa strains. Some strains of $X$. fastidiosa have a wide host range [15], and different strains of $X$. fastidiosa multiply or even cause diseases in the same host $[12,17]$. Most of the studied strains are from economically important hosts. Much less is known about strains on economically unimportant hosts. Strains from economically unimportant or unknown hosts can serve as a reservoir for new disease development [9, 24]. Disease management would be facilitated by a better understanding of the relative suitability of alternate plant hosts to support the multiplication of both the pathogen itself and the many species of insects that act as vectors.

A related question is the ecological roles of $X$. fastidiosa strains in native vegetation, as well as possibly in the vector populations. We speculate that in ecological terms, $X$. fastidiosa could be acting as a natural force to maintain the ecological integrity of the native vegetation. For example, PD may have an ecological role in preventing non-native species such as $V$. labrusca and $V$. vinifera from over-proliferation, which would disrupt the native ecosystem. The Vitis species native to the Southeastern USA grow well in nature but are self-contained.

The recent genomic analysis of $\mathrm{CVC}$ strain $9 \mathrm{a} 5 \mathrm{c}$ shows the absence of both the avirulence (avr) genes and the hypersensitive response and pathogenicity (HRP) gene cluster [28]. This genetic system is used by plant pathogenic bacteria and plants to define and limit the host range. This seems to explain the wide host range of $X$. fastidiosa. Xylella fastidiosa is also unique in that it proliferates only in non-living plant or insect parts. Colonization of plant and insect parts by $X$. fastidiosa may be restricted primarily by nutrition, in a manner similar to that of endophytic microorganisms. Disease may occur as a result of too 'perfect' a match between what the plant host provides and what the bacterium requires, which then would allow the bacterium to multiply to high population levels. The replacement of native floras with their presumably large heterogeneous population of $X$. fastidiosa strains, each adapted to different plant hosts, with extensive monocultures would select for this outcome.

\section{ACKNOWLEDGMENTS}

This work was supported in part by the U.S. Department of Agriculture Capacity Building Grant 96-38814-2868 and the Florida State Matching Fund. We thank E. Civerolo and D. Hopkins for their critical reviews of this manuscript. 


\section{Literature Cited}

1. Albibi R, Chen J, Banks D, Lamikanra O, Jarret RL, Smith BJ (1998) RAPD fingerprinting Xylella fastidiosa Pierce's disease strains from a vineyard in North Florida. FEMS Microbiol Lett 165:374-352

2. Brlansky RH, Davis CL, Timmer LW, Howd DS, Contreras J (1991) Xylem-limited bacteria in citrus from Argentina with symptoms of citrus variegated chlorosis. Phytopathology 81:1210 (Abstract)

3. Chen J, Chang CJ, Jarret RL, Gawel N (1992) Genetic variation among Xylella fastidiosa strains. Phytopathology 82:973-977

4. Chen J, Lamikanra O, Chang CJ, Hopkins DL (1995) Randomly amplified polymorphic DNA analysis of Xylella fastidiosa Pierce's disease and oak leaf scorch pathotypes. Appl Environ Microbiol 61:1688-1690

5. Chen J, Jarret R, Qin X, Hartung JS, Banks D, Chang, CJ, Hopkins DL (2000) 16S rDNA analysis of Xylella fastidiosa strains. Syst Appl Microbiol 23:349-354

6. Da Costa PI, Franco CF, Miranda VS, Teixeira DC, Hartung JS (2000) Strains of Xylella fastidiosa rapidly distinguished by arbitrarily primed-PCR. Curr Microbiol 40:279-282

7. Davies FS, Albrigo LG (1994) Citrus. Oxon, UK: CAB International

8. DeLima JEO, Miranda VS, Hartung JS, Brlansky RH, Coutinho A, Roberto SR, Carlos EF (1998) Coffee leaf scorch bacterium: axenic culture, pathogenicity, and comparison with Xylella fastidiosa of citrus. Plant Dis 82:94-97

9. Freitag JH (1951) Host range of Pierce's disease virus of grapes as determined by insect transmission. Phytopathology 41:920-934

10. Hampl V, Pavlicek A, Flegr J (2001) Construction and bootstrap analysis of DNA fingerprinting-based phylogenetic trees with the freeware program FreeTree: application to trichomonad parasites. Int J Syst Evol Microbiol 51:731-735

11. Hancock JF (1992) Plant evolution and the origin of crop species. Englewood Cliffs, NJ: Prentice-Hall, Inc.

12. Hendson M, Purcell AH, Chen D, Smart C, Guilhabert M, Kirkpatrick B (2001) Genetic diversity of Pierce's disease strains and other pathotypes of Xylella fastidiosa. Appl Environ Microbiol 67:895-903

13. Hewitt Wm B (1958) The probable home of Pierce's disease virus. Plant Dis Rep 42:211-215

14. Hopkins DL (1988) Production of diagnostic symptoms of blight in citrus inoculated with Xylella fastidiosa. Plant Dis 72:432-435

15. Hopkins DL (1989) Xylella fastidiosa: xylem limited bacterial pathogen of plants. Annu Rev Phytopathol 27:271-290

16. Kostka SJ, Tattar TA, Sherald JL, Hurtt SS (1986) Mulberry leaf scorch, a new disease caused by a fastidious xylem-inhabiting bacterium. Plant Dis 70:690-693

17. Li W-B, Pria WD, Teixera DC, Miranda VS, Ayres AJ, Franco CF, Costa MG, Hartung JS (2001) Coffee leaf scorch caused by a strain of Xylella fastidiosa from citrus. Plant Dis 85:501-505

18. Leu LS, Su CC (1993) Isolation, cultivation, and pathogenicity of Xylella fastidiosa, the causal bacterium of pear leaf scorch disease in Taiwan. Plant Dis 77:642-646

19. Metha A, Rosato YB (2001) Phylogenetic relationships of Xylella fastidiosa strains from different hosts, based on 16S rDNA and 16S-23S intergenic spacer sequences. Int J Syst Microbiol 51:311318

20. Phillips PA (1999) Vineyards, almond orchards threatened. American Fruit Grower 119(10):18F-18H

21. Pooler MR, Hartung JS (1995) Genetic relationships among strains of Xylella fastidiosa from RAPD-PCR data. Curr Microbiol 31: 134-137

22. Purcell AH, Saunders SR, Hendson M, Grebus ME, Henry MJ (1999) Causal role of Xylella fastidiosa in oleander leaf scorch disease. Phytopathology 89:53-58

23. Qin X, Miranda VS, Machado MA, Lemos EGM, Hartung JS (2001) An evaluation of the genetic diversity of Xylella fastidiosa isolated from diseased citrus and coffee in Sao Paulo, Brazil. Phytopathology 91:599-605

24. Raju BC, Goheen AC, Frazier NW (1983) Occurrence of Pierce's disease bacteria in plants and vectors in California. Phytopathology 73:1309-1313

25. Rosato YB, Neto JR, Miranda VS, Carlos EF, Manfio GP (1998) Diversity of a Xylella fastidiosa population isolated from Citrus sinensis affected by citrus variegated chlorosis in Brazil. Syst Appl Microbiol 21:593-598

26. Rossetti V, Garnier M, Bové JM, Beretta MJ, Teixera DC, Quaggio JA, DeNegri JD (1990) Presence de bacteries dan le xylem d'orangers atteint de chlorose variegee une nouvelle maladie des agrumes au Brazil. C.R. Acad. Sci. (Paris) 310:345-349

27. Saitou N, Nei M (1987) The neighbor-joining method: a new method for reconstructing phylogenetic trees. Mol Biol Evol 4:406-425

28. Simpson AJG, Reinach FC, Arruda P, et al. (2000) The genome sequence of the plant pathogen Xylella fastidiosa. Nature 406:151157

29. Thompson JD, Gibson TJ, Plewniak F, Jeanmougin F, Higgins DG (1997) The Clustal X windows interface: flexible strategies for multiple sequence alignment aided by quality analysis tools. $\mathrm{Nu}-$ cleic Acids Res 24:4876-4882 